\title{
Hubungan Komunikasi Partisipatif dan Modal Sosial terhadap Keberlanjutan Ekologi Ekowisata Mangrove Desa Teluk Naga
}

\author{
${ }^{1}$ Denny Putra Jayanegara, ${ }^{2}$ Rustono Farady Marta, ${ }^{3}$ Muhamad Isnaini \\ ${ }^{1}$ Universitas Bunda Mulia \\ Email: ${ }^{1}$ dennyputraj@gmail.com,r2rmarta@bundamulia.ac.id,,emisnaini@gmail.com
}

\section{Article Info}

Submitted: 6 January 2021

Revised: 6 March 2021

Accepted: 13 April 2021

Published: 20 July 2021

Keywords: participatory communication, social capital, ecology, mangrove ecotourism.
Kata kunci: komunikasi partisipatif, modal social, ekologi, ekowisata mangrove.

Abstract

This study aims to determine how much the relationship between participatory communication and social capital towards ecological sustainability in mangrove ecotourism in Teluk Naga Village, Teluk Naga Subdistrict, Tangerang Regency. The purpose of this study was to affect how much the relationship between participatory communication and social capital on ecological sustainability in mangrove ecotourism in Teluk Naga Village, Teluk Naga Subdistrict, Tangerang Regency. The research method used is a quantitative approach supported by a qualitative approach. The population in this study was all members of the Ecotourism board of Teluk Naga Tangerang, totaling 32 respondents and all members were utilized as research samples. Data were analyzed using the Microsoft Excel 2016 application and IBM SPSS Statistics 25 for Windows. The results indicated that hypothesis 1 can be accepted by showing a significant relationship between the level of participatory communication and the level of ecological sustainability and hypothesis 2 is also accepted, this is indicated by a strong and significant relationship between social capital and the level of ecological sustainability with the coefficient value. Correlation and sig value. It was concluded that the higher the participatory communication, the higher the ecological sustainability of the Teluk Naga Village Mangrove Ecotourism and the higher the social capital, the higher the sustainability of the Ecological Mangrove Ecotourism in Teluk Naga Village.

Abstrak
Penelitian ini bertujuan untuk mengetahui seberapa besar hubungan
komunikasi partisipatif dan modal sosial terhadap keberlanjutan
ekologi di ekowisata mangrove di desa teluk naga, Kecamatan Teluk
Naga, Kabupaten Tangerang. Jenis Penelitian yang digunakan dalam
penelitian ini yaitu mix-method. Adapun jenis penelitian campuran
ini dengan menggunakan strategi eksplanatoris sekuensia. Populasi
dalam penelitian ini adalah seluruh anggota pengurus Ekowisata


Teluk Naga Tangerang yang berjumlah 32 responden dan semua anggota digunakan sebagai sampel penelitian. Data dianalisis dengan menggunakan aplikasi Microsoft Excel 2016 dan IBM SPSS Statistics 25 for Windows. Hasil penelitian menunjukkan bahwa adanya hubungan yang cukup signifikan antara tingkat komunikasi parsitisipatif dengan tingkat keberlanjutan ekologi dengan nilai koefisien korelasi $+0.409^{* *}$ dan nilai sig. 0.000 dan adanya hubungan yang yang kuat dan signifikan antara modal sosial dengan tingkat keberlanjutan ekologi dengan nilai koefisien korelasi korelasi $+0.610^{* *}$ dan nilai sig. 0.000. Disimpulkan bahwa semakin tinggi komunikasi partisipatif maka semakin tinggi keberlanjutan ekologi ekowisata mangrove Desa Teluk Naga dan semakin tinggi modal sosial, maka semakin tinggi keberlanjutan keberlanjutan ekologi ekowisata mangrove Desa Teluk Naga.

\section{PENDAHULUAN}

Desa Teluk Naga adalah sebuah desa yang terletak di Kecamatan Teluk Naga, Kabupaten Tangerang. Desa ini memiliki berbagai potensi wisata diantaranya keindahan ekosistem hutan mangrove, wisata pemancingan, dan kuliner khas berupa bandeng tulang lunak serta perahu wisata (Fikri Jamal 2019). Namun kerusakan lingkungan di Desa Teluk Naga dari tahun ke tahun terus meningkat di mana hutan mangrove di Kecamatan Teluk Naga memiliki luas mencapai 1.192 ha namun mengalami perubahan (konversi) dari tahun 1997 hingga tahun 2006 hingga mencapai 85,91\% (Fikri Jamal 2019). Pengalih fungsian lahan menyebabkan kerusakan lingkungan dan mengancam keberlangsungan ekosistem mangrove yang pada khususnya di Desa Teluk Naga, sehingga diperlukan sebuah solusi untuk menjaga kelestarian lingkungan dan sumber daya pesisir di Desa Teluk Naga terutama ekosistem hutan mangrovenya. Ekowisata dapat menjadi solusi yang tepat untuk menjaga kelestarian ekosistem dan sumber daya pesisir, karena ekowisata bentuk wisata yang berbasis pada sumber daya pesisir dan laut dengan menyertakan aspek pendidikan dan interpretasi terhadap lingkungan alami dan budaya masyarakat dengan pengelolaan kelestarian ekosistem pesisir dan laut (Runa, 2015).

Wisata pantai dan wisata bahari adalah kegiatan wisata yang dapat dikembangkan dengan konsep ekowisata bahari. Wisata mangrove adalah salah satu kegiatan wisata pantai yang berpotensi untuk dikembangkan di Desa Muara. Hutan mangrove secara ekologis mempunyai peran penting sebagai pelindung pantai dari adanya bahaya tsunami, penahan erosi, perangkap sedimen, pendaur hara, penjaga produktivitas perikanan, peredam laju intrusi air laut, penyangga kesehatan, penjaga keanekaragaman hayati, dan penopang ekosistem pesisir lainnya. Ekosistem mangrove memberikan banyak sekali manfaat bagi manusia sehingga ekosistem ini sangat penting untuk dijaga keberlanjutannya dan dapat dijadikan sebagai objek dari ekowisata bahari itu sendiri. Adanya keberlanjutan ekologi ekowisata mangrove akan membuat masyarakat dapat merasakan manfaat dari keberadaan hutan mangrove sekaligus ikut berkontribusi dalam mengkonservasinya. Pengembangan kawasan ekowisata mangrove ini tidak akan berdampak buruk pada lingkungan jika dilakukan perencanaan dan pengelolaan yang memperhatikan kondisi ruang terbuka hijau terutama mangrove (Rachman and Mardiana 2018).

Atas dasar itu komunikasi partisipatif menjadi penting diupayakan untuk mendorong pengambilan keputusan dalam penerapan tindakan pada pembangunan salah satunya pembangunan ekowisata (Msibi \& Penzhorn, 2010). Dialog antar warga dalam membangun ekowisata sebagai prinsip berlangsungnya komunikasi partisipatif dilakukan dengan tujuan merangkum solusi yang ada untuk penyelesaian bersama (Estriana and Umaimah Wahid 2019). Dalam dialog, setiap warga dan masyarakat di sekitar wisata teluk naga memiliki hak yang sama untuk berbicara atau 
didengar (Muchtar et al., 2015). Penelitian tentang komunikasi partisipatif merujuk pada konsep komunikasi pembangunan partisipatif tidak hanya sebatas hadir dalam berbagai pertemuan dan kegiatan, tetapi lebih kepada menempuh cara-cara dialog dalam pengambilan keputusan (Muchtar et al. 2015).

Modal sosial memfokuskan pada hubungan antar individu demi mencapai pembangunan bersama (Bulu, Hariyadi, et al., 2009). Potensi sumber daya alam yang terdapat di ekowisata mangrove di Desa Teluk Naga, Kecamatan Teluk Naga, Kabupaten Tangerang sangat menarik untuk dikembangkan. Pengembangan ekowisata tidak hanya didukung oleh potensi sumber daya alam, tetapi juga oleh dukungan masyarakat lokal sebagai modal utama untuk pengembangan ekowisata. Hal ini sesuai dengan pernyataan (Badriyah et al. 2014) yaitu bahwa ekowisata memiliki lima karakteristik utama, yaitu nature based, ecologically sustainable, environmentally educative, bermanfaat untuk masyarakat lokal dan kepuasan wisatawan (Ranggadara, Wang, and Kaburuan 2019). Masyarakat sebagai modal utama untuk pengembangan kegiatan ekowisata di dalamnya terdapat proses yang ditopang oleh nilai dan norma yang khas, yaitu kerjasama yang dibangun diatas kepercayaan dengan ditopang oleh nilai-nilai sosial serta jejaring sosial yang dapat membawa kemajuan bersama atau biasa disebut dengan modal sosial (Ahmad, Ariyadi, and Kurniawati Novita Haryadi 2017).

Pentingnya mengetahui modal sosial dalam pengembangan ekowisata telah dibuktikan oleh beberapa penelitian. Penelitian yang telah dilakukan oleh (Soemarno and Indra Nugroho 2013) di Desa Tambaksari, Pasuruan, Jawa Timur menemukan bahwa pengembangan ekowisata di kawasan itu sangat dipengaruhi oleh jaringan yang diikuti oleh partisipasi masyarakat (Soemarno and Indra Nugroho 2013). Oktadiyani (2010) menemukan bahwa kepercayaan dan norma-norma adalah elemen utama dari modal sosial dalam komunitas zona penyangga Taman Nasional Kutai selain partisipasi, jaringan, dan kepedulian terhadap orang lain dan lingkungan (Thobias, Erwin,. A.K. Tungka, and J.J. Rogahang 2013).

Salah satu kegiatan wisata pantai yang berpotensi untuk dikembangkan di Desa Teluk
Naga adalah wisata mangrove (Ranggadara, Legowo, and Sfenrianto 2019). Secara ekologis mangrove mempunyai peran penting sebagai pelindung pantai dari bahaya tsunami, penahan erosi dan perangkap sedimen, pendaur hara, penjaga produktivitas perikanan, peredam laju intrusi air laut, penyangga kesehatan, penjaga keanekaragaman hayati, dan penopang ekosistem pesisir lainnya (Muis, Sumarmi, and Astina 2016). Ekosistem mangrove memberikan banyak sekali manfaat bagi manusia sehingga ekosistem ini sangat penting untuk dijaga keberlanjutannya dan dapat dijadikan sebagai objek dari ekowisata itu sendiri (Yulis and Akliyah Leli 2019).

Penelitian komunikasi partisipatif dan modal sosial terhadap keberlanjutan ekologi dalam bidang ekowisata masih sangat terbatas, karena pada umumnya modal sosial digunakan dalam pembangunan suatu wilayah (Hasbullah 2006). Dalam rangka pengembangan ekowisata di kawasan mangrove di Desa Teluk Naga, Kecamatan Teluk Naga, Kabupaten Tangerang perlu dilakukan identifikasi unsur komunikasi partisipatif masyarakat dan modal sosial pada masyarakat di desa sekitarnya (Yusriyah et al. 2020). Hal ini disebabkan karena pengembangan potensi objek dan daya tarik wisata alam mangrove di Desa Teluk Naga, Kecamatan Teluk Naga, Kabupaten Tangerang perlu didukung oleh adanya komunikasi partisipatif dan modal sosial pada masyarakat di sekitar kawasan tersebut dan penelitian mengenai komunikasi partisipatif dan modal sosial untuk keberdayaan masyarakat dan keberlanjutan ekologi di ekowisata mangrove di Desa Teluk Naga, Kecamatan Teluk Naga, Kabupaten Tangerang belum pernah dilakukan (Farida et al. 2020). Dari latar belakang dan fenomena permasalahan yang ada di atas maka rumusan masalah dan tujuan penelitian yang akan diangkat dalam penelitian ini adalah untuk mengetahui seberapa besar hubungan komunikasi partisipatif dan modal sosial terhadap keberlanjutan ekologi di ekowisata mangrove di desa teluk naga, kecamatan teluk naga, kabupaten tangerang.

\section{METODE}

Penelitian ini menggunakan pendekatan kuantitatif yang didukung oleh pendekatan 
kualitatif. Pendekatan kuantitatif dilakukan dengan metode survei kepada responden (Achmad et al., 2020). Penelitian metode survei dilakukan untuk mengambil sampel dari suatu populasi melalui kuesioner yang diberikan kepada responden (Sugiyono 2016). Kuesioner diberikan kepada responden dengan tujuan untuk menjawab pertanyaan mengenai modal sosial (tingkat kepercayaan, tingkat norma, tingkat jaringan sosial), tingkat komunikasi partisipasif (pengambilan keputusan, pelaksanaan, menikmati hasil serta evaluasi) dan tingkat keberlanjutan (ekologi). Penelitian ini juga bersifat ekplanatori karena menjelaskan hubungan antar variabel melalui pengujian hipotesa (Arief Muhammad Effendi 2016). Sebelum ke lokasi penelitian, telah dilakukan uji coba sebanyak 10 kuesioner terlebih dahulu di Desa Teluk Naga sehingga peneliti dapat melihat sejauh mana validitas dan reliabilitas kuesioner yang telah dibuat. Latar belakang lokasi uji coba kuesioner dilakukan di Teluk Naga Tangerang dikarenakan modal sosial dan komunikasi partisipatif masyarakat yang sama dengan lokasi penelitian. Aturan dalam penentuan nilai alpha yaitu Nilai (Alpha Cronbach) uji validitas tersebut tidak boleh kurang dari 0.6. Jika nilai alpha $>0.90$ maka reliabilitas sempurna, jika nilai alpha $0.70<$ alpha < 0.90 , maka reliabilitas tinggi, jika nilai alpha $0.70<$ alpha $<0.5$ maka reliabilitas moderat, dan jika nilai alpha $<0.5$ maka dapat dikatakan kuesioner memiliki reliabilitas rendah. Tahapan kegiatan penelitian saat di lapang dapat dilihat pada Gambar 1.

\section{Lokasi dan Waktu Penelitian}

Penelitian ini dilaksanakan di Desa Muara, Kecamatan Teluk Naga, Kabupaten Tanggerang. Desa Muara Ujung ini terletak 10 km di sebelah utara Bandara Soekarno Hatta dan berada di sebelah barat dan selatan dari Kepulauan Seribu. Untuk mencapai Teluk Naga, dapat dilakukan perjalanan melalui jalan tol bandara, menuju ke kawasan pergudangan Jalan Perancis, perempatan Dadap, ke arah barat lalu melewati Kosambi dan Salembaranjati, lalu ke arah utara. Dari desa Salembaranjati, Teluk Naga

Identifikasi populasi berdasarkan pengumpulan data di

Desa Teluk Naga Tangerang dan mengumpulkan data sekunder

Melakukan pendekatan terlebih dahulu dengan informan, dalam hal ini yaitu pemerintahan desa (ketua RW, RT) untuk menanyakan terkait dengan responden yang terlibat dalam pengelolaan ekowisata mangrove dan memenuhi kriteria yaitu merupakan masyarakat yang telah tinggal dan menetap di Desa Teluk Naga sejak tahun 1996 dan terlibat dalam pengelolaan ekowisata.

Melakukan melakukan wawancara dengan menggunakan kuesioner kepada responden yang memenuhi kriteria dan wawancara mendalam dengan informan untuk memperoleh data dan informasi berkaitan dengan partisipasi dan keberlanjutan ekologi.

Melakukan wawancara mendalam terhadap beberapa informan dan tokoh elite desa.

Gambar 1. Tahapan Kegiatan Penelitian 


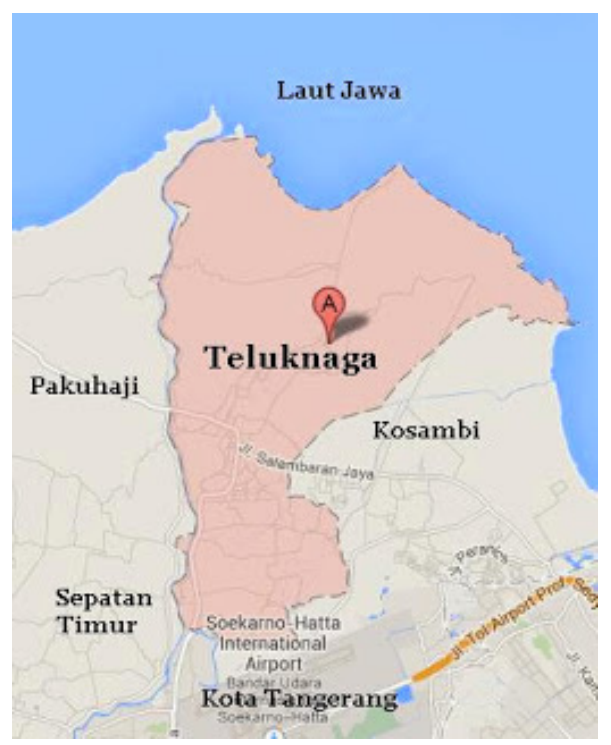

Gambar 2. Peta Desa Teluk Naga Tangerang

dapat dijangkau melalui jalan aspal yang sudah rusak sepanjang kurang lebih $5 \mathrm{~km}$. Lokasi tersebut dipilih secara purposive dikarenakan Ekowisata Mangrove Desa Teluk Naga merupakan salah satu hutan mangrove yang letaknya tidak jauh dari Jakarta yang sedang berkembang dan memiliki daya tarik ekowisata. Waktu penelitian ini di laksanakan selama bulan januari 2021.

\section{Teknik Pengumpulan Data Informan dan Responden}

Sumber data dalam penelitian ini adalah responden dan informan. Unit analisis yang digunakan dalam penelitian ini adalah individu. Populasi dalam penelitian ini adalah seluruh anggota pengurus Ekowisata Teluk Naga Tangerang. Jumlah pengurus yang terdaftar di Ekowisata Teluk Naga Tangerang yaitu 32 orang. Berdasarkan jumlah anggota tersebut, maka pengambilan sampel dilakukan dengan metode sensus yaitu teknik penentuan sampel apabila semua anggota populasi digunakan sebagai sampel penelitian sehingga sampel dalam penelitian ini berjumlah 32 responden (Moleong and Lexy 2015). Informan merupakan orang yang dapat memberikan tambahan informasi sebagai pendukung data penelitian. Pemilihan informan dilakukan dengan sengaja. Informan dalam penelitian ini adalah pihak-pihak yang mengetahui informasi mendalam mengenai Ekowisata Teluk Naga Tangerang, yaitu:
Tabel 1. Informan Penelitian

\begin{tabular}{clc}
\hline Nama & \multicolumn{1}{c}{ Jabatan } & $\begin{array}{c}\text { Jumlah } \\
\text { Informan }\end{array}$ \\
\hline Informan 1 & Kepala Desa Teluk Naga & 1 \\
Informan 2 & $\begin{array}{l}\text { Ketua RT Desa Teluk Naga } \\
\text { Tangerang }\end{array}$ & 1 \\
Informan 3 & $\begin{array}{l}\text { Pengurus Desa Teluk Naga } \\
\text { Tangerang }\end{array}$ & 1 \\
\hline
\end{tabular}

\section{Teknik Pengolahan dan Analisis Data}

Penelitian ini mempunyai dua jenis data yang diolah dan dianalisis, yaitu data kuantitatif dan data kualitatif. Data kuantitatif diolah menggunakan aplikasi Microsoft Excel 2016 dan IBM SPSS Statistics 25 for Windows. Data dianalisis dengan menggunakan tabel frekuensi, tabulasi silang, grafik atau diagram untuk melihat data awal responden untuk masingmasing variabel secara tunggal menggunakan aplikasi Microsoft Excell 2016. IBM SPSS Statistics 25 for Windows digunakan untuk uji statistik yang menggunakan uji korelasi Rank Spearman(One Tail) untuk menganalisis ada atau tidaknya hubungan antar dua variabel yang berskala ordinal. Uji korelasi Rank Spearman dalam penelitian ini digunakan untuk manganalisis hubungan antara komunikasi partisipatif, modal sosial, dengan keberlanjutan ekologi dalam ekowisata mangrove.

Pengolahan data kuantitatif dilakukan dengan menggunakan uji korelasi Rank Spearman untuk melihat hubungan antar variabel dari data yang bersifat ordinal seperti partisipasi masyarakat dan masing-masing keberlanjutan. Selanjutnya partisipasi masyarakat dan masingmasing keberlanjutan diperoleh dengan melihat kemudian mendeskripsikan berdasarkan skor tertinggi. Pengolahan data untuk RankSpearman dilakukan dengan menggunakan SPSS Statistics 25 for Windows guna memperoleh ketepatan, kecepatan proses perhitungan, dan kepercayaan hasil pengujian. Data kualitatif digunakan sebagai data pendukung yang diolah dan dianalisis dengan konten analisis. Pengolahan dan analisis data kualitatif dilakukan dengan mereduksi atau meringkas data dengan menggolongkan, mengarahkan, membuang yang tidak perlu dan mengorganisasikan data sedemikian rupa sehingga sesuai dengan 
keperluan untuk menjawab pertanyaan analisis di dalam penelitian.

\section{HASIL DAN PEMBAHASAN}

\section{Deskriptif Responden}

Sebagian besar responden dalam penelitian ini berusia tua yaitu lebih dari 50 tahun dengan jumlah 17 orang karena sebagian besar responden bergabung dalam pengurus Ekowisata Mangrove di Desa Teluk Naga Tangerang sudah sejak awal berdirinya Ekowisata Mangrove di desa Teluk Naga Tangerang bahkan sebelum Ekowisata Mangrove di desa Teluk Naga Tangerang diresmikan. Mayoritas responden yang menjadi anggota yaitu dari kalangan lakilaki sebanyak 30 orang dan hanya 2 orang yang merupakan responden perempuan. Pendidikan terakhir sebagian besar responden yaitu tamat SMA dengan jumlah 16 orang. Hal tersebut karena sebagian besar penduduk desa Teluk Naga Tangerang memiliki kesadaran yang tinggi terkait pentingnya pendidikan, selain itu juga ditunjang dengan tingkat perekonomian penduduk Ekowisata Mangrove di desa Teluk Naga Tangerang yang juga terbilang tinggi. Responden dalam penelitian ini yaitu pengurus Ekowisata Mangrove di desa Teluk Naga Tangerang yang bekerja sebagai nelayan, petani, pengurus, dan pedagang di sekitar Ekowisata
Mangrove di desa Teluk Naga Tangerang. Jumlah responden paling banyak berdasarkan lama menjadi pengurus yaitu lebih dari sama dengan 24 tahun sebanyak 13 orang karena keterampilan dalam mengurus Ekowisata Mangrove di desa Teluk Naga Tangerang.

\section{Luas dan Letak Kawasan}

Penelitian ini dilaksanakan di Desa Teluk Naga Tangerang secara administratif, Desa Muara terletak di Kecamatan Teluk Naga, Kabupaten Tangerang. Desa Muara terletak di sebelah utara Kecamatan Teluk naga dan jarak dari desa ke kecamatan kurang lebih $10 \mathrm{~km}$. Desa Muara memiliki unsur pembantu Pemerintah terbawah yang terdiri dari 8 dusun, 8 Rukun Warga (RW) dan 22 Rukun Tetangga (RT). Desa Muara memiliki batas yang jelas yaitu berupa aliran sungai Ciliwung. Luas area Desa ini kurang lebih adalah 505 Ha dan merupakan daerah dataran rendah dengan ketinggian $40 \mathrm{~m}$ dari permukaan laut dengan suhu udara $27-33^{\circ} \mathrm{C}$. Batasan tapak yaitu :

a. Sebelah utara berbatasan dengan Laut Jawa.

b. Sebelah timur berbatasan dengan Laut Jawa/Desa Lemo.

c. Sebelah selatan berbatasan dengan Desa Lemo.

d. Sebelah barat berbatasan dengan Desa Tanjung Pasir

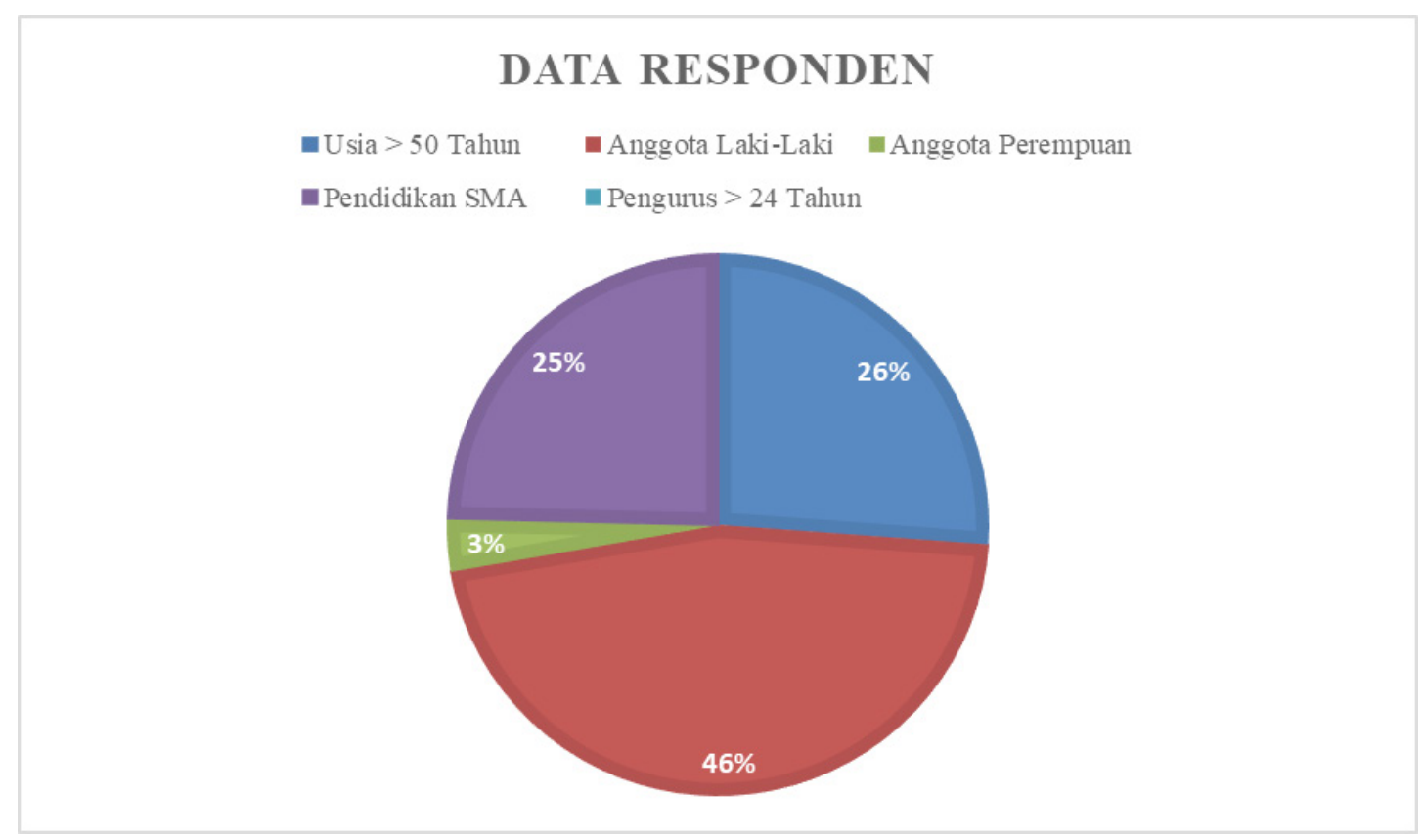

Gambar 3. Data Responden 


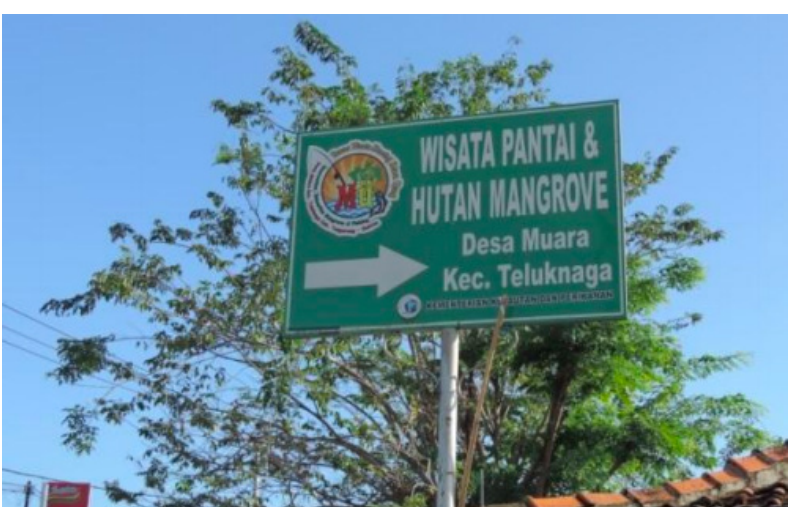

Gambar 4. Akses Utama Menuju Desa Muara

\section{Potensi Ekowisata}

Ekowisata Mangrove di desa Teluk Naga Tangerang merupakan objek dan daya tarik Mangrove yang memiliki keindahan hutan Mangrove yang aman untuk menikmati panorama yang indah, terutama saat terbit dan terbenamnya matahari. Di lokasi ini, terdapat warung-warung untuk peristirahatan, serta tempat yang indah untuk berfoto bagi para wisatawan. Akses ke dalam Desa Muara dapat dicapai dengan melewati Desa Lemo terlebih dahulu, di Desa Lemo pengunjung harus membayar sebesar Rp 8000/mobil dan Rp $10000 /$ motor, dan saat memasuki perbatasan Desa Lemo dan Desa Muara pengunjung di kenakan biaya lagi dengan harga yang sama, hal ini yang membuat pengelolaan wisata ini kurang baik. Sebaiknya kedua desa bekerjasama untuk pengelolaan tiket masuk ini agar tidak terjadi kekecewaan pada pengunjung. Tiket masuk ini di kelola oleh Karang Taruna desa. Hasil dari tiket masuk ini digunakan untuk kegiatan pembangunan desa, seperti pembangunan dan pemeliharaan masjid, uang kas desa, dan perbaikan jalan desa.

\section{Komunikasi Partisipatif dalam Ekowisata Mangrove}

Komunikasi Partisipatif merupakan proses keterlibatan aktif masyarakat dari proses pembentukan keputusan untuk menentukan tujuan, kemudian dalam pelaksanaannya secara sukarela dan merasakan manfaat dari hasil suatu program. Menurut (Cohen and Uphoff 1980) tingkat partisipasi terbagi ke dalam empat tahap yaitu partisipasi tahap pengambilan keputusan, tahap pelaksanaan, tahap menikmati hasil dan tahap evaluasi (Estriana, Umaimah Wahid, and Nawiroh Vera 2020). Sedangkan menurut (Mardikanto dan Totok 2010) Komunikasi Partisipatif merupakan suatu keterlibatan secara aktif, baik alasan dari dalam atau dari luar pada keseluruhan proses kegiatan yang bersangkutan, mencangkup pengambilan keputusan dalam perencanaan, pelaksanaan, pengendalian (pemantauan, evaluasi, dan pengawasan) serta pemanfaatan hasil-hasil kegiatan yang dicapai. Penelitian ini ingin melihat tingkat Komunikasi Partisipatif responden berdasarkan ke-empat tahapan tingkat Komunikasi Partisipatif tersebut.

\section{Tahap Perencanaan}

Tahap perencaan dalam partisipasi merupakan sebuah tahapan awal yang meliputi tahap pengambilan keputusan, keikutsertaan masyarakat dalam kegiatan rapat-rapat. Selain itu, pada tahap perencanaan ini diukur berdasarkan keaktifan responden dalam memberikan pendapat serta keaktifan dalam pengambilan keputusan bersama-sama saat musyawarah dalam perencanaan awal Ekowisata Desa Teluk Naga.

Tabel 2 menunjukkan bahwa tingkat partisipasi masyarakat dalam ekowisata mangrove Desa Teluk Naga Tangerang pada tahap perencanaan berada pada kategori tinggi yaitu sebesar 53 persen. Tingginya dalam perencanaan pada kegiatan ekowisata dalam mengikuti dan menghadiri rapat, memberikan saran maupun pendapatnya dalam proses merencanakan suatu kegiatan, perundingan dan pengambilan keputusan dilakukan berdasarkan hasil keputusan bersama. Masyarakat yang tergolong sedang dan rendah pada tahap perencanaan ini dikarenakan tidak berani jika keputusan berada ditangannya atau jarang memberikan pendapatnya. Berikut pernyataan

Tabel 2. Tingkat Komunikasi Partisipatif pada awal perencanaan

\begin{tabular}{lcc}
\hline $\begin{array}{c}\text { Tahap } \\
\text { Perencanaan }\end{array}$ & $\begin{array}{c}\text { Frekuensi } \\
\text { (orang) }\end{array}$ & $\begin{array}{c}\text { Persentase } \\
\text { (\%) }\end{array}$ \\
\hline Rendah & 7 & 21.09 \\
Sedang & 8 & 25.0 \\
Tinggi & 17 & 53.1 \\
Total & 32 & 100 \\
\hline
\end{tabular}


salah satu responden: "Masyarakat di sini kalau ada rapat banyak yang hadir mas. Tapi ya kadang ada yang rajin hadir kadang juga nggak. Pas waktu rapat ada yang ngasih pendapatnya, ya ada juga yang cuma dengerin, diem gak ngasih pendapat. Masukan-masukan dari warga ya kami bahas bersama mas. Biasanya bahas tentang tempat pengembangan wisata mas. Biasanya kalau pengunjung yang datang banyak berapa rombongan gitu, kan jadi butuh banyak ruang.". (Informan,1).

\section{Tahap Pelaksanaan}

Tingkat partisipasi pada tahap pelaksanaan yaitu keikutsertaan masyarakat ekowisata mangrove Desa Teluk Naga Tangerang dilihat dari kehadiran dalam rapat yang dilaksanakan, keikutsertaan dalam kepengurusan, keikutsertaan dalam memberikan atraksi dan akomodasi kepada para wisatawan, keikutsertaan dalam pelatihan yang membantu meningkatkan keterampilan dalam melayani dan mengembangkan ekowisata. Masyarakat ekowisata mangrove Desa Teluk Naga Tangerang sendiri mayoritas bekerja sebagai petani dan nelayan karena potensi ekowisata mangrove Desa Teluk Naga Tangerang sebagian besar terdapat pada sektor perkebunan dan perikanan. Masyarakat juga banyak yang menjadi pemandu wisata yang dilakukan seperti, menanam mangrove, memancing. Jumlah dan persentase menurut tingkat komunikasi partisipatif pada tahap pelaksanaan.

Tabel 3 menunjukkan bahwa tingkat partisipasi masyarakat pada tahap pelaksanaan yang tergolong tinggi yaitu sebesar 62 persen. Hal ini dikarenakan seluruh responden berperan aktif dan melaksanakan kegiatan-kegiatan, mulai dari membersihkan lingkungan dari sampah, pengadaan pembuangan air limbah, menjaga

Tabel. 3 Tingkat Komunikasi Partisipatif pelaksanaan

\begin{tabular}{lcc}
\hline $\begin{array}{c}\text { Tahap } \\
\text { Perencanaan }\end{array}$ & $\begin{array}{c}\text { Frekuensi } \\
\text { (orang) }\end{array}$ & $\begin{array}{c}\text { Persentase } \\
\text { (\%) }\end{array}$ \\
\hline Rendah & 7 & 21.09 \\
Sedang & 5 & 15.0 \\
Tinggi & 20 & 62.0 \\
Total & 32 & 100 \\
\hline
\end{tabular}

kualitas air, pembangunan fasilitas wisata dan kelestarian tanaman serta penanaman mangrove. Namun tidak semua responden terlibat bekerja di lapangan ketika wisatawan berkunjung ke lokasi ekowisata. Berikut pernyataan salah satu responden: "Masyarakat disini biasanya bekerja ya sesuai ada permintaan pengunjung atau tidak, mas. Biasanya pengunjung rombongan yang mau datang itu ngontak admin pemandu wisata mas, nah nanti admin ngontak pengurus. Biasanya sih mbak pengurus yang bisa bantu beberapa pengunjung untuk edukasi dan bisa sekalian jadi pemandu mas". (Informan,2).

\section{Tahap Menikmati Hasil}

Tingkat partisipasi pada tahap menikmati hasil merupakan keikutsertaan dalam menerima hasil, manfaat dan keuntungan yang diperoleh oleh masyarakat yang terlibat dalam pengelolaan ekowisata. Tahap menikmati hasil ini diukur berdasarkan hasil kelestarian alam yang dapat dimanfaatkan serta hasil pendapatan dari usaha masyarakat. Jumlah dan persentase menurut tingkat partisipasi masyarakat pada tahap menikmati hasil.

Tabel 4 menunjukkan tingkat partisipasi pada tahapan menikmati hasil tergolong tinggi, sebesar 81,25 persen dari responden. Hal ini dikarenakan masyarakat merasakan manfaat dan mendapatkan keuntungan dari kawasan ekowisata, seperti pemanfaatan sumber daya alam perikanan, sumber daya alam perkebunan, dan warung-warung kecil. Berikut pernyataan salah satu responden: "Dari hasil penjualan kalau pengunjungnya banyak yah cukup nambahin kebutuhan keluarga mas, jadi pemandu ekowisata juga gak setiap hari tergantung pengunjungnya. Biasanya masyarakat disini mancing kalau dapet banyak ya dijual, kalau sedikit untuk makan bareng keluarga. Atau dari hasil kebun ada yang

Tabel. 4 Tingkat Komunikasi Partisipatif Menikmati Hasil

\begin{tabular}{lcc}
\hline $\begin{array}{c}\text { Tahap } \\
\text { Perencanaan }\end{array}$ & $\begin{array}{c}\text { Frekuensi } \\
\text { (orang) }\end{array}$ & $\begin{array}{c}\text { Persentase } \\
\text { (\%) }\end{array}$ \\
\hline Rendah & 2 & 2.5 \\
Sedang & 4 & 12.5 \\
Tinggi & 26 & 81.25 \\
Total & 32 & 100 \\
\hline
\end{tabular}


bisa dipanen besoknya dijual. Hasil kebun yah pisang, cengkeh, kopi, coklat mbak. (Informan,3)

\section{Modal Sosial dalam Ekowisata Mangrove}

Modal Sosial memiliki pengertian dan dimensi yang beragam. Colleta dan Cullen (dalam Soemarno and Indra Nugroho 2013) mendefinisikan modal sosial sebagai suatu sistem yang mengacu kepada atau hasil dari organisasi sosial dan ekonomi, seperti padangan umum, kepercayaan, pertukaran timbal-balik, pertukaran ekonomi dan informasi, kelompokkelompok formal dan informal, serta asosiasiasosiasi yang melengkapi modal-modal lainnya (fisik, manusiawi, budaya) sehingga memudahkan terjadinya tindakan kolektif, pertumbuhan ekonomi, dan pembangunan. Penelitian ini menggunakan 3 dimensi modal sosial seperti kepercayaan, norma, dan jaringan sosial untuk dianalisis kemudian diuji pengaruhnya terhadap tingkat partisipasi responden. Pengertian modal sosial dengan tiga dimensi kepercayaan, norma, dan jaringan sosial menurut (Bulu, Hariadi, and Herianto 2009) adalah bagian dari organisasi sosial seperti kepercayaan, norma, serta jaringan yang dapat meningkatkan efisiensi masyarakat untuk memfasilitasi tindakan-tindakan yang terkoordinasi sehingga dimensi dari modal sosial menurut (Bulu, Hariadi, et al. 2009) yang utama adalah kepercayaan, norma, serta jaringan sosial. Jumlah dan presentase responden menurut tingkat modal sosial tahun 2018.

Berdasarkan data pada Tabel 5, tingkat modal sosial responden tergolong tinggi dengan jumlah responden 14 orang atau 43.75 persen. Sisanya berada pada tingkat sedang dengan jumlah 12 orang atau 37.5 persen, dan tingkat rendah dengan jumlah 6 orang atau 18.75 persen. Tingkat modal sosial ini diperoleh dari tiga dimensi yaitu tingkat kepercayaan, tingkat

Tabel. 5 Tingkat Modal Sosial

\begin{tabular}{lcc}
\hline $\begin{array}{c}\text { Tingkat Modal } \\
\text { Sosial }\end{array}$ & $\begin{array}{c}\text { Frekuensi } \\
\text { (orang) }\end{array}$ & $\begin{array}{c}\text { Persentase } \\
\text { (\%) }\end{array}$ \\
\hline Rendah & 6 & 18.7 \\
Sedang & 12 & 37.5 \\
Tinggi & 14 & 43.75 \\
Total & 32 & 100 \\
\hline
\end{tabular}

norma, dan tingkat jaringan sosial. Modal sosial yang tinggi terlihat dari antar responden yang sudah saling percaya satu sama lain, saling tolong menolong, saling memahami bahwa setiap responden memiliki kondisi yang berbeda-beda, dan hubungan yang terjalin baik dengan semua responden. "Kalau ada warga yang mau minta tolong pinjam uang, kalau aku ada ya pasti aku tolong mas, orang ya udah tak anggap seperti saudara sendiri" (SA, 28 tahun).

Modal sosial yang tinggi ini juga terlihat dari akses responden dalam mendapatkan informasi. Untuk jumlah dan presentase responden menurut masing-masing dimensi modal sosial.

Berdasarkan tabel 6 dua dimensi modal sosial, yaitu tingkat kepercayaan dan tingkat jaringan sosial berada pada kategori tinggi, sedangkan tingkat norma berada pada kategori sedang menuju tinggi. Hal tersebut karena responden kurang mematuhi peraturan yang diterapkan. Seperti halnya terkait dengan kebersihan, kerja bakti. Tingkat kepercayaan responden yang tinggi dikarenakan antar responden sudah saling mengenal satu sama lain sehingga menumbuhkan rasa saling percaya di antara responden. Tingkat jaringan sosial yang tinggi dikarenakan kemudahan akses informasi yang diperoleh responden, selain itu terjalin hubungan yang baik antara responden dengan ketua, pengurus, maupun dengan responden lain.

Tabel 6. Jumlah dan Presentase Responden menurut Masing-Masing Dimensi Modal Sosial

\begin{tabular}{llcc}
\hline Modal Sosial & Kategori & $\begin{array}{c}\text { Frekuensi } \\
\text { (orang) }\end{array}$ & $\begin{array}{c}\text { Persentase } \\
(\%)\end{array}$ \\
\hline \multirow{2}{*}{ Tingkat } & Rendah & 7 & 21.09 \\
Kepercayaan & Sedang & 8 & 25.0 \\
& Tinggi & 17 & 53.1 \\
Total & Total & 32 & 100 \\
\hline \multirow{2}{*}{ Tingkat } & Rendah & 10 & 31.2 \\
Norma & Sedang & 11 & 34.4 \\
& Tinggi & 11 & 34.4 \\
Total & Total & 32 & 100 \\
\hline Tingkat & Rendah & 4 & 12.5 \\
Jaringan & Sedang & 9 & 28.1 \\
Sosial & Tinggi & 19 & 59.4 \\
Total & Total & 32 & 100 \\
\hline
\end{tabular}




\section{Keberlanjutan Ekologi Mangrove}

Keberlanjutan ekologi adalah cara menciptakan sistem berkelanjutan berbasis lingkungan dengan memelihara sumber daya alam agar tetap dalam keadaan stabil, menghindari terjadinya eksploitasi alam agar kawasan lingkungan dapat melakukan fungsi secara sempurna. Aspek lingkungan yang alamiah dalam ekowisata merupakan aspek utama ciri khas ekowisata. Keterlibatan masyarakat dalam menjaga kelestarian lingkungan dan memanfaatkan sumber daya alam akan mempengaruhi perkembangan ekowisata. Manusia hidup bergantung dengan lingkungan, begitu pula dengan lingkungan yang membutuhkan perawatan manusia. Keberlanjutan ekowisata bergantung pada lingkungan, maka masyarakat diharapkan dapat terlibat untuk merawatnya. Masyarakat beranggapan bahwa dengan menjaga lingkungan mereka akan menikmati hasil dan menerima manfaat yang baik pula dari lingkungan. Apabila lingkungan rusak tidak hanya generasi saat ini yang mengalami akibatnya, namun juga generasi mendatang yang akan merasakannya. Analisis tingkat keberlanjutan ekologi diukur berdasarkan dua indikator yaitu tingkat kelestarian lingkungan dan tingkat pemanfaatan sumberdaya alam.

Hasil yang telah direpresentasikan oleh indikator kelestarian lingkungan dan pemanfaatan sumberdaya alam, kemudian ditarik menjadi sebuah simpulan, yaitu tingkat keberlanjutan ekologi responden secara umum. Cara menarik simpulan tersebut dengan mengkategorikan nilai jawaban responden dari seluruh pertanyaan indikator tingkat keberlanjutan ekologi.

Tabel. 7 Tingkat Keberlanjutan Ekologi Ekowisata

\begin{tabular}{lcc}
\hline $\begin{array}{c}\text { Tingkat Modal } \\
\text { Sosial }\end{array}$ & $\begin{array}{c}\text { Frekuensi } \\
\text { (orang) }\end{array}$ & $\begin{array}{c}\text { Persentase } \\
\text { (\%) }\end{array}$ \\
\hline Rendah & 1 & 3.1 \\
Sedang & 2 & 6.25 \\
Tinggi & 29 & 90.6 \\
Total & 32 & 100 \\
\hline
\end{tabular}

Berdasarkan Tabel 7 persentase tingkat keberlanjutan ekologi kawasan ekowisata mangrove desa teluk naga Tangerang sebesar 90.6\% tergolong dalam kategori tinggi. Hal ini berdasarkan observasi di lapang, masyarakat selalu menjaga kebersihan lingkungan dan mampu memanfaatkan sumberdaya alam yang ada seperti perikanan maupun perkebunan dengan baik. Fasilitas yang ada seperti warung yang di bangun di sekitar ekowisata dibangun dengan baik, tanpa mengganggu atau mencemari lingkungan.

\section{Hubungan Komunikasi Partisipatif dan Modal Sosial terhadap Keberlanjutan Ekologi Ekowisata Mangrove Desa Teluk Naga}

Komunikasi Partisipatif masyarakat dan modal sosial sering dikaitkan dengan kegiatan pembangunan dalam masyarakat. Keberhasilan suatu pembangunan ditentukan oleh peran serta dan partisipasi masyarakat. Komunikasi Partisipatif dalam ekowisata mangrove akan lebih efektif dan berhasil bila sesuai dengan keinginan masyarakat kawasan ekowisata. Pengujian akan diuji menggunakan uji statistik korelasi non-parametrik rank spearman karena ketiga variabel tersebut memiliki data dengan skala ordinal. Uji korelasi Rank Spearman merupakan pengujian antar variabel yang berhubungan yang diolah dengan menggunakan program SPSS 25. Ketentuan hipotesis diterima, apabila nilai signifikan lebih kecil dari $\alpha(0.05)$, sebaliknya jika nilai yang didapatkan lebih besar dari $\alpha(0.05)$, maka hubungan antara dua variabel tersebut tidak signifikan, dilanjutkan dengan melihat aturan nilai correlation coeficient mengenai kekuatan hubungan antara dua variabel menurut Sarwono (2006) sebagai berikut: 0.00 (tidak ada hubungan/korelasi antara dua variable), 0.250.5 (korelasi cukup), >0.5-0.75 (korelasi kuat), >0.75-0.99 (korelasi sangat kuat), 1 (korelasi sempurna). Nilai $\alpha$ merupakan nilai signifikan antar variabel dan rs merupakan nilai koefisien korelasi Rank Spearman. Koefisien korelasi komunikasi terhadap keberlanjutan ekologi.

Pada tabel 8 menunjukkan hasil olah menggunakan uji statistik Rank Spearman bahwa koefisien korelasi tingkat komunikasi partisipatif terhadap keberlanjutan ekologi memiliki hubungan yang cukup karena berada pada rentang $>0.25-0.5$. hal ini dapat di lihat. 
Tabel 8. Korelasi Tingkat Hubungan Komunikasi Partisipatif dan Modal Sosial terhadap Keberlanjutan Ekologi Ekowisata Mangrove Desa Teluk iNaga

Correlations

\begin{tabular}{|c|c|c|c|c|}
\hline & & $\begin{array}{c}\text { Komunikasi } \\
\text { Partisipatif }\end{array}$ & $\begin{array}{l}\text { Modal } \\
\text { Sosial } \\
\end{array}$ & $\begin{array}{c}\text { Keberlanjutan } \\
\text { Eologi } \\
\end{array}$ \\
\hline \multirow{3}{*}{ Komunikasi Partisipatif } & Pearson Correlation & 1 & 1 & $.409^{* *}$ \\
\hline & Sig. (2-tailed) & & & .000 \\
\hline & $\mathrm{N}$ & 32 & 32 & 32 \\
\hline \multirow{3}{*}{ Modal Sosial } & Pearson Correlation & 1 & 1 & $.610^{* *}$ \\
\hline & Sig. (2-tailed) & & & .000 \\
\hline & $\mathrm{N}$ & 32 & 32 & 32 \\
\hline \multirow{3}{*}{ Keberlanjutan Eologi } & Pearson Correlation & $.409^{* *}$ & $.610^{* *}$ & 1 \\
\hline & Sig. (2-tailed) & .000 & .000 & \\
\hline & $\mathrm{N}$ & 32 & 32 & 32 \\
\hline
\end{tabular}

Berdasarkan observasi di lapangan, masyarakat desa teluk naga memiliki kesadaran tinggi akan pentingnya kelestarian lingkungan, dinmana masyarakat selalu mengadakan kegiatan kerja bakti setiap dua minggu sekali. Selain itu masyarakat desa teluk naga ikut dalam kegiatan pelestarian sumberdaya yang ada dengan tidak mengeksploitasi dalam memanfaatkan sumber daya alam yang ada, kegiatan pelestarian sumber daya tersebut meliputi penanaman pohon mangrove, menjaga keanekaragaman tanaman, memjaga kebersihan dan mengadakan pengembangbiakan atau pelestarian ikan.

Sedangkan koefisien korelasi modal sosial terhadap keberlanjutan ekologi memiliki hubungan yang kuat karena berada pada rentang $>0.5-0.75$. Modal sosial responden didapatkan dari tingkat kepercayaan, tingkat norma, dan tingkat jaringan sosial. Tingginya modal sosial responden dikarenakan antar responden sudah saling mengenal satu sama lain sehingga menumbuhkan rasa saling percaya antar responden yang kemudian membuat responden mau untuk saling tolong menolong. Rasa saling percaya antar responden yang kemudian membuat responden merasa nyaman untuk melakukan setiap kegiatan dan melancarkan kegiatan demi berlangsungnya tingkat ekologi mangrove di desa teluk naga. Modal sosial yang berkembang di tengah masyarakat tertentu merupakan faktor yang signifikan dalam penguatan (pelemahan) partisipasi masyarakat (Thobias, Erwin et al. 2013). Putnam dalam
Hasbullah (2006) menyatakan bahwa modal sosial yang tinggi akan membawa dampak pada tingginya partisipasi masyarakat dalam berbagai bentuk kegiatan pembangunan. Berbagai program pembangunan yang dilaksanakan akan jauh lebih efektif jika dilakukan pada masyarakat yang memiliki modal sosial yang kuat.

\section{SIMPULAN}

Berdasarkan hasil dan pembahasan maka pada penelitian Hubungan Komunikasi Partisipatif dan Modal Sosial terhadap Keberlanjutan Ekologi Ekowisata Mangrove Desa Teluk Naga di peroleh beberapa simpulan sebagai berikut :

a. Pada Hasil penelitian ini ditunjukkan oleh adanya hubungan yang cukup dan signifikan antara tingkat komunikasi parsitisipatif dengan tingkat keberlanjutan ekologi dengan nilai koefisien korelasi $+0.409^{* *}$ dan nilai sig. 0.000 bahwa semakin tinggi komunikasi partisipatif maka semakin tinggi keberlanjutan ekologi Ekowisata Mangrove Desa Teluk Naga. Komunikasi Partisipatif mendukung dalam memelihara kelestarian lingkungan dan mampu memanfaatkan sumberdaya alam yang ada dengan bijak tanpa mengeksploitasinya.

b. Pada Penelitian ini ditunjukkan oleh adanya hubungan yang yang kuat dan signifikan antara modal sosial dengan tingkat keberlanjutan ekologi dengan 
nilai koefisien korelasi $+0.610^{* *}$ dan nilai sig. 0.000 bahwa semakin tinggi modal sosial, maka semakin tinggi keberlanjutan keberlanjutan Ekologi Ekowisata Mangrove Desa Teluk Naga. Modal sosial yang tinggi dalam setiap kegiatan dan saling bahu membahu dan gotong-royong sehingga kehidupan masyarakat tentram terhindar dari konflik

\section{PERSANTUNAN}

Ucapan terima kasih disampaikan kepada masyarakat Desa Teluk Naga Tangerang, Kepala Desa Teluk Naga Tangerang, Dosen Pembimbing saya, serta semua pihak yang telah mendukung dan membantu pelaksanaan kegiatan ini.

\section{REFERENSI}

Achmad, Zainal Abidin, Juwito, Saud, And Muhammad. (2020). “The Local Creative Ads On Sritanjung Fm To Increase Financial Revenue During Covid-19 Pandemic". Bricolage : Jurnal Magister Ilmu Komunikasi 6(2):135-46.

Ahmad, Romadhoni Raden, Surya Putra Bambang Ariyadi, And Kurniawati Novita Haryadi. (2017). "Pengaruh Modal Sosial terhadap Tingkat Kesejahteraan Rumah Tangga Peternak: Studi Kasus pada Kelompok Peternak Ayam Kampung Ngudi Mulyo, Gunungkidul”. Buletin Peternakan 41:349-54.

Arief Muhammad Effendi. (2016). The Power Of Corporate Governance Teori dan Implementasi. Jakarta: Salemba Empat.

Badriyah, Muntasib H, Rachmawati E, Meilani R, Mardianti A, Sunkar A, And Kosmaryandi. (2014). Rekreasi Alam Dan Ekowisata. Bogor: IPB Press.

Bulu, Yohanes G., Sunarru S. Hariadi, And Ageng S. Herianto. (2009). "Pengaruh Modal Sosial dan Keterdedahan Jagung di Kabupaten Lombok Timur Nusa Tenggara Barat”. Jurnal Agro Ekonomi 27(Mei):1-21.

Bulu, Yohanes G., Sunnaru S. Hariyadi, Ageng. S. Heriyanto, And Mudiyono. (2009). "Pengaruh Modal Sosial dan Keterdedahan Informasi Inovasi terhadap Tingkat Adopsi Inovasi Jagung di Kabupaten Lombok Timur Nusa Tenggara Barat". Jurnal Argo Ekonomi 27(1):1-21.

Cohen, John M., And Norman T. Uphoff. (1980). "Participation's Place in Rural Development: Seeking Clarity Through Specificity”. World Development 8(3):213-35.

Estriana, Virna, And Umaimah Wahid. 2019. “Erving Goffman's Approach In Perspective and SelfPresentation of Transgender in Tambun Bekasi”. International Journal of Multidisciplinary Research And Publications 2(2):71-77.

Estriana, Virna, Umaimah Wahid, And Nawiroh Vera. (2020). "Analisa Strategi Ecommerce Indonesia dalam Penerapan Integrated Marketing Communication". Jurnal Ilmiah Fakultas Ilmu Komputer $9(1)$.

Farida, Zulaikha, Putro, And Hartopo Eko. (2020). “Decentralization of Indonesian Religious Tourism Trough City Branding of Bangkalan Madura Regency". Bricolage : Jurnal Magister Ilmu Komunikasi 6(2):223-34.

Fikri Jamal. (2019). “Peran Pemerintah Daerah dalam Pengelolaan Wilayah Pesisir”. Jurnal Komunikasi Hukum Dan Budaya 2(1).

I Wayan Runa. (2015). "Pembangunan Berkelanjutan Berdasarkan Konsep Tri Hita Karana untuk Kegiatan Ekowisata”. Jurnal Kajian Bali 2(1).

Mardikanto Dan Totok. (2010). Konsep-Konsep Pemberdayaan Masyarakat. Surakarta: UNS Press. 
Moleong, And J. Lexy. (2015). "Metodologi Penelitian Kuantitatif”. Bandung: PT Remaja Rosdakarya.

Msibi, Futhi, And Cecilia Penzhorn. (2010). "Participatory Communication for Local Government in South Africa: A Study of the Kungwini Local Municipality." Information Development 26(3):22536.

Muchtar, Karmila, Ninuk Purnaningsih, And Djoko Susanto. (2015). "Participative Communication in Field School of Comprehensive Agriculture Land-Use Management (Sl-Ptt)”. Jurnal Komunikasi Pembangunan 12(2).

Muis, Arifuddin Abd, Sumarmi, And I. Komang Astina. (2016). "Strategi Pengembangan Ekowisata Bahari Sebagai Sumber Belajar Geografi Pariwisata.” Jurnal Pendidikan Komunikasi: Teori, Penelitian, Dan Pengembangan 1(11):2178-88.

Rachman, Mohammad Irfan, And Rina Mardiana. (2018). "Hubungan Partisipasi Masyarakat dengan Keberlanjutan Ekologi, Sosial-Budaya dan Ekonomi dalam Ekowisata Religi". Jurnal Sains Komunikasi Dan Pengembangan Masyarakat [Jskpm] 2(4):509.

Ranggadara, Indra, Nilo Legowo, And Sfenrianto. (2019). "Migrating Applications to Clouds With Togaf Framework At Meraki Digital Indonesia". Journal of Theoretical And Applied Information Technology 97(9).

Ranggadara, Indra, Gunawan Wang, And Emil Robert Kaburuan. (2019). “Applying Customer Loyalty Classification with Rfm and Naïve Bayes for Better Decision Making". Pp. 564-68 In 2019 International Seminar On Application For Technology of Information And Communication (Isemantic). Ieee.

Soemarno, Baksh, And Indra Nugroho. (2013). "Modal Sosial dalam Pengembangan Ekowisata: Studi Kasus di Desa Tambaksari Kabupaten Pasuruan Provinsi Jawa Timur Indonesia”. J Basic Appl. Sci Res, 3(3):1-7.

Sugiyono. 2016. Metode Penelitian Kuantitatif Kualitatif dan R\&D. Bandung: Alfabeta.

Thobias, Erwin, Msi.. A.K. Tungka, And Msi.. J.J. Rogahang. (2013). "Pengaruh Modal Sosial terhadap Perilaku Kewirausahaan (Suatu Studi pada Pelaku Usaha Mikro Kecil Menengah di Kecamatan Kabaruan Kabupaten Kepulauan Talaud)". Journal "Acta Diurna” 3(2).

Yulis, Asyiwat, And Akliyah Leli. (2019). "Identifikasi Dampak Perubahan Fungsi Ekosistem Pesisir terhadap Lingkungan di Wilayah Pesisir Kecamatan Muaragembong”. Jurnal Perencanaan Wilayah Dan Kota 14(1).

Yusriyah, Kiayati, Sudaryanto, Ahmad Fatoni, And Muhammad Akram Mansyur. (2020). “Communication Networks Analysis on Information Dissemination of the Moving of Capital City from Jakarta to East Kalimantan". Aspiration Journal 1(1):31-55. 